\title{
UPAYA PENINGKATAN HASIL BELAJAR PIANO 2 MELALUI METODE SIGHT READING DI JURUSAN PENDIDIKAN SENI MUSIK FBS UNY
}

\author{
Panca Putri Rusdewanti \\ Jurusan Pendidikan Seni Musik, FBS UNY \\ email: panca_putri@uny.ac.id
}

\begin{abstract}
ABSTRAK
Penelitian ini bertujuan untuk mendeskripsikan peningkatan hasil belajar Piano 2 melalui metode sight reading di Jurusan Pendidikan Seni Musik FBS UNY.

Jenis penelitian ini dapat diklasifikasikan sebagai penelitian tindakan kelas dalam dua siklus. Yang setiap siklusnya terdiri (a) perencanaan/persiapan, (b) tindakan, (c) pengamatan, (d) refleksi. Subjek dalam penelitian ini adalah mahasiswa Jurusan Pendidikan Seni Musik yang mengambil mata kuliah Piano 2 sejumlah 20 orang. Tahapan penelitian, yaitu (a) pretest sebagai alat ukur kemampuan awal mahasiswa, (b) post test sebagai evaluasi hasil akhir mahasiswa. Teknik analisis data meliputi analisis secara kuantitatif berupa data ordinal yang dianalisis menggunakan persentase.

Hasil penelitian menunjukkan hasil sebagai berikut. (1) Siklus I sebanyak 10 dari 20 mahasiswa telah tuntas belajar atau 50\% dan mahasiswa yang belum tuntas belajar sebanyak 10 mahasiswa atau 50\%. (2) Siklus II sebanyak 17 dari 20 mahasiswa telah tuntas belajar atau $85 \%$. Jika dilihat dari data diatas maka dapat disimpulkan bahwa penggunaan metode sight reading dapat meningkatkan hasil belajar mata kuliah Piano 2 semeter genap tahun ajaran 2013/2014 jurusan pendidikan seni musik FBS UNY.
\end{abstract}

Kata kunci: sight reading, proses pembelajaran, prestasi belajar. 


\title{
IMPROVEMENT EFFORTS OF THE LEARNING OUTCOMES IN PIANO 2 THROUGH SIGHT READING METHOD IN DEPARTMENT OF MUSIC EDUCATION FBS UNY
}

\begin{abstract}
This study aims to describe the improvement of the learning outcomes in Piano 2 through sight reading method in the Department of Music Education FBS $U N Y$.

This research can be classified as a class action research in two cycles. Each cycle consists of (a) planning/preparing, (b) action, (c) observation, (d) reflection. The subjects of this research are the students of Music Education Department who take Piano 2 class in a number of 20 students. The stages of research, namely (a) pretest as a measuring tools of student's initial capability, (b) post test as a evaluation of the students final result. The data analysis technique included quantitative analysis in the form of ordinal data which were analyzed using percentages.

The research results are as follows. (1) In Cycle I as many as 10 of the 20 students have been thoroughly studied, or $50 \%$, and students who have not been thoroughly studied as many as 10 students or $50 \%$. (2) In Cycle II as many as 17 of the 20 students have been thoroughly studied, Or $85 \%$. From the above data it can be concluded that the use of sight reading method can improve the learning outcomes of Piano 2 Class in the second semester of academic year 2013/2014 in the Department of Music Education FBS UNY.
\end{abstract}

Keywords: sight reading, learning process, learning achievement.

\section{A. PENDAHULUAN}

Universitas Negeri Yogyakarta merupakan salah satu perguruan tinggi yang mempunyai Jurusan Pendidikan Seni Musik yang menyelenggarakan pembelajaran piano. Pembelajaran Piano di jurusan ini terbagi dalam mata kuliah yang bersifat wajib dan khusus. Mata kuliah piano wajib terdiri atas mata kuliah piano 1 dan piano 2, sedangkan yang bersifat khusus terdiri atas PIM 1 piano, PIM 2 Piano, dan PIM 3 Piano. Mata kuliah Piano 2 diselenggarakan pada semester genap. Pada mata kuliah piano 2 sumber belajar yang dapat dimanfaatkan oleh mahasiswa adalah penyampaian materi oleh dosen atau praktisi dan buku teks. Teknik atau metode belajar yang digunakan adalah demonstrasi, 
role play, dan tutorial. Strategi dan model pembelajaran yang telah dilaksanakan selama ini sudah dianggap dapat membantu mahasiswa dalam belajar. Namun pada kenyataannya tidak semua mahasiswa dapat menguasai kompetensi dengan mudah. Ada banyak kendala yang dirasakan diantaranya waktu yang tersedia sangat terbatas, jumlah mahasiswa dalam satu kelas relatif cukup banyak, diperlukan pendekatan individual, tingkat pemahaman yang berbeda antar mahasiswa, sebagian besar mahasiswa tidak memiliki instrumen piano menyebabkan mahasiswa sangat bergantung pada sarana yang ada dikampus yang jumlah dan pemakaiannya sangat terbatas, serta motivasi mahasiswa untuk belajar mandiri dirasakan kurang oleh peneliti

Hal tersebut dirasakan peneliti dalam proses pembelajaran diantaranya pada saat kuliah mahasiswa belum siap dengan tugas yang telah diberikan selama satu minggu, sehingga saat bermain piano banyak kesalahan yang dibuat mahasiswa. Sehingga perlu diupayakan metode yang tepat sehinggga mahasiswa secara tidak sadar dipaksa untuk mengerjakan materi yang diberikan. Untuk menunjang keberhasilan dalam pembelajaran Piano 2, peran dosen diharapkan dapat menentukan kualitas pembelajaran yang baik. Sehubungan dengan ini, dosen hendaknya selalu memikirkan tentang bagaimana upaya yang dilakukan untuk meningkatkan kualitas pembelajaran tersebut, diantaranya dengan membuat perencanaan pembelajaran dengan seksama dan menyiapkan sejumlah perangkat pembelajaran yang tepat guna. Disamping itu, dalam kaitannya dengan peningkatan kualitas pembelajaran ini, dosen juga dituntut agar dapat mengupayakan terciptanya kondisi pembelajaran yang efektif. Upaya ini menurut Usman (2008:16) .... "menuntut perubahan-perubahan dalam pengorganisasian kelas, penggunaan metode mengajar, strategi pembelajaran, sikap dan karakter dosen dalam mengelola proses pembelajaran dengan bertindak selaku fasilitator yang berusaha menciptakan kondisi pembelajaran yang efektif dengan cara meningkatkan kemampuan mahasiswa untuk menyimak pelajaran dengan melibatkan mahasiswa secara aktif, berupaya menarik minat dan perhatian mahasiswa terhadap pelajaran, dan membangkitkan motivasi belajar. “ 
Permasalahan penelitian ini dapat dirumuskan sebagai berikut: Bagaimana Peningkatan Hasil Belajar Piano 2 melalui Metode Sight Reading di Jurusan Pendidikan Seni Musik FBS UNY?

\section{B. KAJIAN TEORI}

Musik adalah bahasa emosi yang bersifat universal. Melalui pendengaran musik dapat dimengerti dan dirasakan makna dan kesan yang terkandung didalamnya. Manusia normal sejak lahir sudah dibebani dengan kemampuan reaksi terhadap bunyi atau musik. Sehingga tanpa kegiatan mendengar, manusia-manusia tidak dapat memberikan reaksi terhadap rangsangan yang berbentuk bunyi (Jamalus, 1981 : 49). Selanjutnya dikemukakan pula bahwa dalam mempelajari teori musik, harus diberikan melalui bunyinya, sehingga mahasiswa dapat mendengar dan menghayati apa yang disebut dengan tangga nada, interval, melodi dan acord.

\section{Sight reading}

Sight Reading adalah membaca not tanpa persiapan (Last 1980 : 135). Selanjutnya dinyatakan bahwa sight reading adalah kesanggupan sekaligus untuk membaca dan memainkan notasi musik yang belum pernah dikenal sebelumnya. Hal ini sering disebut dengan istilah prima vista. Kennedy (1985 : 667) mendefinisikan sight reading sebagai berikut: " The reading of music at first sight in order to performance it". Selain berfungsi untuk meningkatkan kemampuan membaca dan menambah pengetahuan tentang bahasa musik, sight reading juga berfungsi untuk menemukan hal-hal baru dalam musik dan memberikan kenikmatan dalam bermusik bagi pemain atau penyaji musik hingga pada tingkat ketrampilan (kemahiran ) yang tinggi.

Untuk dapat menguasai sight reading dibutuhkan banyak latihan yang teratur. Namun demikian bukan banyaknya latihan yang penting melainkan latihan-latihan (meskipun sedikit) yang dilakukan tiap hari secara teratur dan terus-menerus akan lebih dirasakan manfaatnya (Last 1980 : 136). Florentinus (1997 : 60) membagi lebih lanjut kemampuan membaca not (sight reading) ke 
dalam tiga indikator kemampuan, yaitu: (1) kemampuan membaca ritme/irama, (2) kemampuan membaca melodi/rangkaian nada, dan (3) kemampuan membaca acord/keselarasan gabungan nada.

\section{Pembelajaran Piano}

Nada tidak dapat dilihat atau diperhatikan, tetapi dapat didengar ataupun diperdengarkan. Nada adalah bunyi yang getarannya teratur. Untuk menuliskan nada, digunakan notasi (simbol). Pada dasarnya, notasi hanya dapat melukiskan dua sifat nada, yaitu tinggi rendah dan panjang pendek. Dengan notasi, kita dapat mengenal, membaca, menulis, dan menyanyikan lagu. Dalam musik, pada umumnya digunakan dua sistem penulisan, yaitu sistem yang menggunakan not angka dan not balok. Notasi balok adalah simbol atau tanda untuk menyatakan tinggi atau rendahnya suara yang diwujudkan dengan gambar. Materi yang diajarkan berkaitan dengan pengenalan not balok adalah bentuk not balok, nama dan nilai ketukan not balok, garis paranada, bentuk dan nilai tanda diam, tanda kunci, birama, tanda accidental, dan tangga nada. Seperti halnya alat musik lain, piano memiliki teknik tersendiri dalam memainkannya. Teknik tersebut antara lain teknik penjarian (fingering), sentuhan (touching), dinamika, teknik menggunakan pedal (pedaling).(Rere Aley, 2001: 70). Teknik penjarian piano adalah suatu teknik mengenai tata cara kesesuaian membunyikan nada dengan penjarian dalam penekanan tuts piano, dengan maksud memberikan penjelasan bagaimana cara memainkannya. Teknik penjarian piano mempunyai bermacam fungsi dalam permainannya. Dengan teknik ini diharapkan seorang pianis mampu memainkan karya musik dengan penjarian yang sesuai dengan keinginan sang komponis, disamping memberikan kemudahan kepada pianis agar nyaman dalam memainkannya.

\section{METODE PENELITIAN}

Penelitian ini merupakan Penelitian Tindakan Kelas. Penelitian ini dilakukan di Jurusan Pendidikan Musik FBS UNY pada mata kuliah Piano 2 Kelas L semester genap tahun ajaran 2013/2014. Subyek penelitian ini adalah 
mahasiswa jurusan pendidikan seni musik yang mengambil mata kuliah piano 2 kelas L berjumlah 20 orang.

Variabel penelitian dikelompokkan menjadi tiga, yaitu: (1) Variabel input meliputi kondisi awal siswa, persiapan dosen dan mahasiswa, serta keberadaan sarana dan prasarana yang menunjang dan menarik perhatian siswa dalam pembelajaran musik, (2) Variabel proses meliputi kondisi proses pembelajaran piano 2 dengan metode sight reading dengan evaluasi tiap siklus,

Dalam penelitian ini dipilih model Spiral ( Kemmis dan Taggart, 1988) dengan langkah-langkah meliputi: (1) perencanaan/persiapan; (2) tindakan ((3) pengamatan; (4) refleksi. Model Kemmis \& McTaggart merupakan pengembangan dari konsep dasar yang diperkenalkan oleh Kurt Lewin sebagaimana yang diutarakan di atas. Hanya saja, komponen acting (tindakan) dengan observing (pengamatan) dijadikan sebagai satu kesatuan. Disatukannya kedua komponen tersebut disebabkan oleh adanya kenyataan bahwa antara implementasi acting dan observing merupakan dua kegiatan yang tidak terpisahkan. Maksudnya, kedua kegiatan haruslah dilakukan dalam satu kesatuan waktu, begitu berlangsungnya suatu tindakan begitu pula observasi juga harus dilaksanakan. Untuk lebih tepatnya, berikut ini dikemukakan bentuk designnya (Kemmis \& McTaggart, 1990:14).

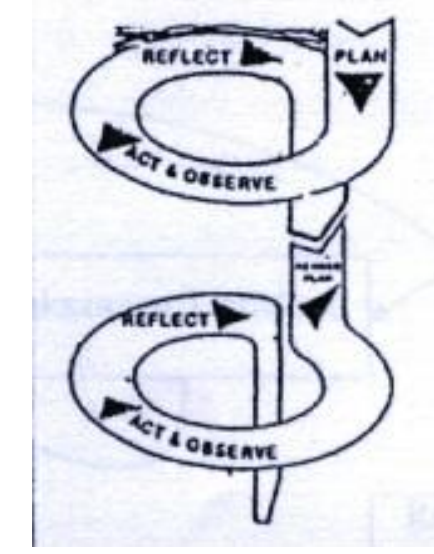

Gambar 1. Model Penelitian Tindakan dari Kemmis \& McTaggart 
Apabila dicermati, model yang dikemukakan oleh Kemmis \& McTaggart pada hakekatnya berupa perangkat-perangkat atau untaian-untaian dengan satu perangkat terdiri dari empat komponen, yaitu perencanaan, tindakan, pengamatan dan refleksi. Keempat komponen yang berupa untaian tersebut dipandang sebagai satu siklus. Oleh karena itu, pengertian siklus pada kesempatan ini adalah suatu putaran kegiatan yang terdiri dari perencanaan, tindakan, pengamatan dan refleksi.

Pada gambar diatas, tampak bahwa didalamnya terdiri dari dua perangkat komponen yang dapat dikatakan sebagai dua siklus. Untuk pelaksanaan sesungguhnya, jumlah siklus sangat bergantung kepada permasalahan yang perlu diselesaikan. Apabila permasalahan terkait dengan mata pelajaran tidak hanya terdiri dari dua siklus,

Pengumpulan data diperoleh melalui: (1) Dokumentasi hasil belajar piano mahasiswa setelah pembelajaran; (2) Evaluasi atau hasil belajar yang dilakukan setiap akhir siklus. Data yang diperoleh diolah dengan: (1) Pengecekan kelengkapan data; (2) Pentabulasian data; dan (3) Analisis data. Analisis data yang digunakan dalam penelitian ini adalah analisis deskriptif dengan prosentase yang memaparkan data yang diperoleh dari hasil pelaksanaan tindakan yang mencakup hasil belajar siswa. Indikator keberhasilan akan tampak pada evaluasi tiap siklus. Dapat dikatakan tuntas jika nilai rata-rata kelas diatas 75 dan tidak tuntas jika nilai rata-rata kelas dibawah 75 .

\section{HASIL PENELITIAN}

\section{Hasil Penelitian Siklus I}

Langkah awal yang dilakukan peneliti sebelum melaksanakan penelitian tindakan kelas, yaitu melakukan pengamatan awal berupa kegiatan pra tindakan tanpa mengganggu pembelajaran untuk mengetahui keadaan awal yaitu kemampuan dalam membaca notasi balok.. Selain melakukan pengamatan peneliti juga melakukan penilaian terhadap aktifitas yang dilakukan mahasiswa dalam kegiatan pembelajaran. Sebelum melakukan penelitian tindakan kelas, dilakukan pra observasi untuk melihat prestasi belajar. Peneliti akan meningkatkan hasil belajar Piano 2 melalui media metode sight reading agar keberhasilan peneliti 
dapat terlihat dengan jelas maka dilakukan pra observasi sebagai perbandingan sebelum dilakukan tindakan kelas dan sesudah tindakan kelas. Pelaksanaan siklus I ini dilaksanakan sebanyak tiga kali pertemuan yaitu pada hari Selasa 30 April, Selasa 5 Mei dan Selasa 12 Mei 2014. Dalam setiap pertemuan mahasiswa membaca notasi balok dengan pokok bahasan melodi, harmoni, serta perpaduan melodi dengan harmoni.

Pada tahap perencanaan tindakan, hal-hal yang dilakukan adalah sebagai berikut: (1) Membuat rencana kegiatan pembelajaran yang akan dilakukan dalam tiga kali pertemuan bersama kolaborator, (2)Mempersiapkan lembar observasi yang akan digunakan untuk memperoleh data selama pelaksanaan penelitian, (3) Mempersiapkan materi yang akan digunakan dalam pembelajaran.

Dalam pelaksanaan penelitian siklus I peneliti berkolaborasi dengan kolaborator. Tugas kolaborator adalah mengamati,menilai dan mendokumentasikan semua kegiatan yang dilakukan mahasiswa. Sedangkan tugas dosen adalah melaksanakan kegiatan belajar mengajar sesuai dengan RPP yang disusun dan telah didiskusikan sebelumnya. Pertemuan pertama dilaksanakan pada hari Selasa 30 April 2014 dengan jumlah mahasiswa yang mengikuti pembelajaran pada siklus I pertemuan I sebanyak 20 mahasiswa. Dosen mengkondisikan mahasiswa untuk duduk di depan piano masing-masing.. Kegiatannya adalah mahasiswa diminta untuk membaca notasi balok secara langsung dengan fokus pada tangan kanan atau melodi. Selanjutnya dosen akan meminta mahasiswa memainkan melodi sendiri-sendiri secara bergantian dengan sesekali membimbing mahasiswa yang mengalami kesulitan. Pertemuan kedua dilakanakan pada hari Selasa 5 Mei 2014. Dosen mengkomunikasikan kepada mahasiswa kegiatan yang akan dilakukan hari ini hampir, yaitu membaca notasi balok dengan fokus harmoni. Kegiatannya adalah mahasiswa diminta untuk membaca notasi balok secara langsung dengan fokus pada tangan kiri atau harmoni. Selanjutnya dosen akan meminta mahasiswa memainkan harmoni sendiri-sendiri secara bergantian dengan sesekali membimbing mahasiswa yang mengalami kesulitan. Pertemuan ketiga dilaksanakan pada hari Selasa 12 Mei 2014. Dosen mengkomunikasikan kepada mahasiswa kegiatan yang akan 
dilakukan hari ini yaitu membaca notasi balok dengan fokus perpaduan melodi dengan harmoni. Kegiatannya adalah mahasiswa diminta untuk membaca notasi balok secara langsung dengan fokus pada tangan kiri dan tangan kiri. Selanjutnya dosen akan meminta mahasiswa membaca notasi balok secara langsung dan memainkan pada piano sendiri-sendiri secara bergantian dengan sesekali membimbing mahasiswa yang mengalami kesulitan.

Selanjutnya observasi dilakukan oleh peneliti beserta kolaborator yang telah bersedia membantu peneliti selama penelitian berlangsung. Dari hasil pengamatan yang dilakukan oleh peneliti bersama dengan kolaborator terhadap proses pembelajaran pada siklus I dapat dilihat, sebagai berikut: (1) Selama proses pembelajaran mulai dari kegiatan awal, kegiatan inti, dan kegiatan akhir, mahasiswa serius melakukan apa yang diperintahkan dosen. Berdasarkan observasi pada siklus I peneliti mengamati proses belajar yang dilakukan mahasiswa. Mahasiswa terlihat lebih serius dalam mengikuti perkuliahan, karena mereka mendapatkan tugas yang harus dikerjakan saat itu juga dan langsung dievaluasi. Kesempatan untuk berbicara dengan teman dapat diminimalkan karena tiap mahasiswa sibuk berlatih.

Hasil pengamatan terhadap prestasi belajar dapat dilihat pada siklus I di bawah ini:

Tabel 1. Rekapitulasi Data Prestasi belajar Siklus I

\begin{tabular}{|l|c|c|c|}
\hline No & Kriteria & $\begin{array}{c}\text { Jumlah } \\
\text { mahasiswa }\end{array}$ & Persentase \\
\hline 1 & Tuntas & 10 & $50 \%$ \\
\hline 2 & Tidak tuntas & 10 & $50 \%$ \\
\hline
\end{tabular}


Dari hasil data rekapitulasi pada tabel 1, dapat diketahui jumlah mahasiswa yang mencapai ketuntasan belajar 10 mahasiswa dan mahasiswa yang belum mencapai ketuntuasan belajar sebanyak 10 mahasiswa. Setelah pelaksanaan siklus I sudah tidak ada mahasiswa yang belum mencapai ketuntasan belajar Pembelajaran piano untuk meningkatkan prestasi belajar mahasiswa kelas $\mathrm{L}$ telah menunjukkan adanya peningkatan yang lebih baik dari segi kemampuan mahasiswa.

Peningkatan kemampuan membaca permulaan pada silkus I diketahui dengan cara membandingkan perolehan persentase peningkatan prestasi belajar sebelum diberi tindakan dan setelah diberi tindakan. Berdasarkan data penelitian yang diperoleh terdapat peningkatan jumlah mahasiswa yang mencapai ketuntasan belajar Dari kegiatan pra tindakan 20 mahasiswa yang memiliki kemampuan membaca dengan kriteria cukup persentase 33,3\% dan setelah pelaksanaan tindakan siklus I meningkat menjadi 10 mahasiswa atau 50\%. Pelaksanaan refleksi dilakukan peneliti bersama patner dosen dengan melihat perbandingan antara data sebelum dilakukan tindakan dan setelah dilakukan tindakan pada siklus I. Peningkatan kemampuan mahasiswa pada pembelajaran Piano 2 khususnya membaca notasi balok pada siklus I dapat diketahui dengan cara membandingkan perolehan persentase kemampuan mahasiswa sebelum diberikan tindakan dan setelah diberikan tindakan. Ada beberapa kendala saat pelaksanaan tindakan pada siklus I antara lain: (1) Metode yang digunakan yaitu kegiatan pembelajaran secara klasikal kurang tepat, (2) Waktu yang tersedia untuk belajar kurang, sehingga mahasiswa belum maksimal saat belajar

Berdasarkan dari hasil penelitian dan saran kolaborator, beberapa hal yang harus diperhatikan pada tindakan selanjutnya adalah sebagai berikut: (1) Metode yang aktif dan dosen lebih maksimal dalam membimbing mahasiswa, (2) Memberikan kesempatan kepada mahasiswa untuk belajar membaca notasi balok dan memberikan bimbingan kepada setiap mahasiswa agar kemampuan mahasiswa lebih dapat terlihat peningkatannya, (3) Mengatur waktu seefisien mungkin agar pembelajaran maksimal. 


\section{Hasil Pelaksanaan Siklus II}

Pelaksanaan siklus I ini dilaksanakan mahasiswa sebanyak tiga kali pertemuan yaitu pada hari Selasa 19 Mei, Selasa 26 Mei dan Selasa 3 Juni 2013. Dalam setiap pertemuan mahasiswa akan mengulang apa yang sudah dilakukan pada siklus I dengan materi berbeda dengan tingkat kesulitan yang sama. Melihat keadaan dalam pelaksanaan siklus I masih ada beberapa kendala, maka dalam tahap perencanaan tindakan siklus II ini perlu diadakan suatu rencana perbaikan atau perubahan dalam pelaksanaan pada siklus II sehingga kendala-kendala yang terjadi pada siklus I dapat teratasi. Rencana tindakan yang akan dilakukan pada siklus II untuk perbaikan yaitu: (1) Siklus I pembelajaran lebih menekankan pembelajaran klasikal dan pada siklus II masih menggunakan pembelajaran klasikal serta ditambah dengan pembelajaran idividu agar mahasiswa bisa mendapat bimbingan secara intensif dari dosen, (2) Memberikan kesempatan kepada mahasiswa untuk membaca notasi balok saat itu juga, (3) Menggunakan waktu secara efektif dalam melakukan pembelajaran

Dalam pelaksanaan penelitian siklus II peneliti berkolaborasi dengan kolaborator.. Tugas kolaborator adalah mengamati, menilai dan mendokumentasikan semua kegiatan yang dilakukan mahasiswa. Sedangkan tugas dosen adalah melaksanakan kegiatan belajar mengajar sesuai dengan RPP yang disusun dan telah didiskusikan sebelumnya. Berikut ini deskripsi proses pelaksanaan tindakan siklus II: (1) Pertemuan pertama dilaksanakan pada hari Selasa 19 Mei 2012 Jumlah mahasiswa yang mengikuti pembelajaran pada siklus II pertemuan I sebanyak 20 mahasiswa. Dosen mengkondisikan mahasiswa untuk duduk di depan piano masing-masing.. Kegiatannya adalah mahasiswa diminta untuk membaca notasi balok secara langsung dengan focus pada tangan kanan atau melodi. Selanjutnya dosen akan meminta mahasiswa memainkan melodi sendiri-sendiri secara bergantian dengan sesekali membimbing mahasiswa yang mengalami kesulitan, (2) Pertemuan kedua dilaksanakan pada hari Selasa 26 Mei 2014. Dosen mengkomunikasikan kepada mahasiswa kegiatan yang akan dilakukan hari ini. Kegiatannya adalah mahasiswa diminta untuk membaca notasi 
balok secara langsung dengan focus pada tangan kiri atau harmoni. Selanjutnya dosen akan meminta mahasiswa memainkan harmoni sendiri-sendiri secara bergantian dengan sesekali membimbing mahasiswa yang mengalami kesulitan (3) Pertemuan ketiga dilaksanakan pada hari Selasa 5 Juni 2014. Dosen mengkomunikasikan kepada mahasiswa kegiatan yang akan dilakukan hari ini yaitu membaca notasi balok dengan fokus perpaduan melodi dengan harmoni. Kegiatannya adalah mahasiswa diminta untuk membaca notasi balok secara langsung dengan fokus pada tangan kiri dan tangan kiri. Selanjutnya dosen akan meminta mahasiswa membaca notasi balok secara langsung dan memainkan pada piano sendiri-sendiri secara bergantian dengan sesekali membimbing mahasiswa yang mengalami kesulitan.

Observasi dalam penelitian ini dilakukan oleh peneliti beserta kolaborator yang telah bersedia membantu peneliti selama penelitian berlangsung. Dari hasil pengamatan yang dilakukan oleh peneliti terhadap proses pembelajaran membaca notasi balok pada siklus II dapat dilihat, sebagai berikut: Selama proses pembelajaran mulai dari kegiatan awal, kegiatan inti, dan kegiatan akhir, mahasiswa serius melakukan apa yang diperintahkan dosen. Berdasarkan observasi pada siklus I peneliti mengamati proses belajar yang dilakukan mahasiswa. Mahasiswa terlihat lebih serius dalam mengikuti perkuliahan, karena mereka mendapatkan tugas yang harus dikerjakan saat itu juga dan langsung dievaluasi. Kesempatan untuk berbicara dengan teman dapat diminimalkan karena tiap mahasiswa sibuk berlatih.

Hasil pengamatan terhadap prestasi belajar dapat dilihat pada siklus I di bawah ini:

Tabel 3. Rekapitulasi Data Prestasi belajar Siklus I

\begin{tabular}{|l|c|c|c|}
\hline No & Kriteria & $\begin{array}{c}\text { Jumlah } \\
\text { mahasiswa }\end{array}$ & Persentase \\
\hline 1 & Tuntas & 17 & $85 \%$ \\
\hline 2 & Tidak tuntas & 3 & $15 \%$ \\
\hline
\end{tabular}


Dari hasil data rekapitulasi pada tabel 1, dapat diketahui jumlah mahasiswa yang mencapai ketuntasan belajar ada 17 dan jumlah mahasiswa yang belum mencapai ketuntasan belajar ada 3. Setelah pelaksanaan siklus II sudah tidak ada mahasiswa yang memiliki kemampuan membaca dengan kriteria kurang baik. Pembelajaran piano untuk meningkatkan prestasi belajar mahasiswa kelas L telah menunjukkan adanya peningkatan yang lebih baik dari segi kemampuan mahasiswa. Peningkatan kemampuan membaca permulaan pada silkus II diketahui dengan cara membandingkan perolehan persentase peningkatan prestasi belajar pada siklus I dan sijkus II. Berdasarkan data penelitian yang diperoleh terdapat peningkatan jumlah mahasiswa yang mencapai ketuntasan belajar.. Dari kegiatan Siklus I mahasiswa yang mencapai ketuntasan belajar sebanyak 15\% dan setelah pelaksanaan tindakan siklusII ada 17 mahasiswa atau $85 \%$ yang mencapai ketuntasan belajar.Pelaksanaan refleksi dilakukan peneliti bersama patner guru dengan melihat perbandingan antara data siklus I dan siklus II. Peningkatan kemampuan mahasiswa pada pembelajaran bahasa khususnya membaca permulaan pada siklus II dapat diketahui dengan cara membandingkan perolehan persentase kemampuan mahasiswa sebelum diberikan tindakan dan setelah diberikan tindakan.

Berdasarkan dari hasil penelitian dan saran kolaborator, beberapa hal yang harus diperhatikan pada tindakan selanjutnya adalah sebagai berikut: Metode yang digunakan ditambah metode kelompok dan individu agar semua mahasiswa lebih aktif dan dosen lebih maksimal dalam membimbing mahasiswa. memberikan kesempatan kepada mahasiswa untuk belajar membaca notasi balok dan memberikan bimbingan kepada setiap mahasiswa agar kemampuan mahasiswa lebih dapat terlihat peningkatannya dan mengatur waktu seefisien mungkin agar pembelajaran maksimal. Data yang diperoleh selama penelitian berlangsung menunjukkan bahwa prestasi belajar dengan menggunakan metode sight reading benar-benar meningkat. Sehingga dapat disimpulkan bahwa penggunaan metode sight reading dapat meningkatkan prestasi belajar mahasiswa. dengan didapatkannya hasil ini maka peneliti dan kolaborator menghentikan penelitian ini hanya sampai pada siklus II karena pada siklus dua dianggap sudah sesuai dengan hipoteses tindakan yang dilakukan.

\section{E. PEMBAHASAN}


Langkah awal yang dilakukan peneliti sebelum melaksanakan penelitian tindakan kelas, yaitu melakukan pengamatan awal berupa kegiatan pra tindakan untuk mengetahui keadaan awal. Selanjutnya dilakukan pra observasi untuk melihat kemampuan sight reading mahasiswa. Peneliti akan meningkatkan hasil belajar Piano 2 melalui metode sight reading. Agar keberhasilan peneliti dapat terlihat dengan jelas maka dilakukan pra observasi sebagai perbandingan sebelum dilakukan tindakan kelas dan sesudah tindakan kelas. Sebagai tindak lanjut dari proses pembelajaran dan hasil belajar studi awal yang sangat rendah, maka peneliti melakukan Penelitian Tindakan Kelas dengan melakukan proses pembelajaran siklus I. Sesuai dengan jadwal yang ditentukan, proses pembelajaran siklus I dilakukan pada tanggal 30 April 2014. Peneliti memberikan pengarahan pada mahasiswa yang akan dikerjakan hari itu kemudian meminta mahasiswa maju satu per satu ke depan dan melakukan sight reading. Peneliti memberikan bimbingan pada saat sight reading. Hasil yang didapat ada mahasiswa bekerja sama yang antusias antusias dan aktif, namun ada juga mahasiswa yang kebingungan karena selama ini belajar dengan melihat/menirukan teman saja.

Hasil belajar mahasiswa setelah dilaksanakannya siklus I mengalami peningkatan, meskipun hanya sedikit. Pada siklus I nilai rata-rata kelas 65. Jumlah mahasiswa yang mencapai ketuntasan belajar ada 10 mahasiswa atau $50 \%$ dari jumlah mahasiswa. Mahasiswa yang belum tuntas belajar ada 10 atau sekitar 50\%.. Dari data tersebut dapat disimpulkan bahwa penguasaan materi sudah meningkat, meskipun belum optimal, yaitu 10 mahasiswa dari 20 mahasiswa (50\%) sudah mencapai ketuntasan belajar.

Siklus II dilaksanakan sebagai tindak lanjut dari proses pembelajaran dan hasil belajar pada siklus I yang belum optimal. Siklus II dilaksanakan pada tanggal 6 Mei 2014. Pada siklus II ini mahasiswa telah terlihat percaya diri. Hal ini dimungkinkan mahasiswa telah terbiasa melakukan sight reading. Materi pada siklus II ini berbeda dengan siklus I tetapi mempunyai tingkatan yang sama. Setelah 20 mahasiswa selesai maju satu per satu, peneliti memberikan penguatan 
dan evaluasi. Hasil belajar mahasiswa setelah dilaksanakannya siklus II mengalami peningkatan yang baik. hanya ada beberapa mahasiswa yang kesulitan. Pada siklus I nilai rata-rata kelas 74. Jumlah mahasiswa yang mencapai ketuntasan belajar ada 17 mahasiswa atau $85 \%$ dari jumlah mahasiswa. Mahasiswa yang belum tuntas belajar ada 3 atau sekitar $15 \%$.

Proses pembelajaran pada siklus I mengalami peningkatan bila dibandingkan dengan studi awal pembelajaran. Proses pembelajaran pada studi awal aktivitas dan motivasi mahasiswa belum muncul, hal ini disebabkan tidak semua mahasiswa melatih materi pembelajaran dengan maksimal. Proses pembelajaran pada siklus I aktivitas mahasiswa mulai terlihat dan motivasi mahasiswa dalam proses pembelajaran juga meningkat. Hal ini disebabkan sudah adanya perubahan metode pembelajaran. Peneliti tidak hanya mengevaluasi apa yang ditugaskan sebelumnya tetapi juga meminta mahasiswa untuk mengerjakan tugas pada saat perkuliahan berlangsung. Dalam proses pembelajaran tersebut peneliti juga telah memberikan bimbingan kepada mahasiswa yang mengalami kesulitan.

Peningkatan aktivitas dan motivasi dalam pembelajaran siklus I memang telah mengalami peningkatan, namun peningkatan tersebut menurut peneliti belumlah optimal, sehingga peneliti melanjutkan PTK dalam siklus II. Jika pada studi awal ketuntasan belajar mahasiswa secara klasikal hanya 20\% atau mahasiswa yang tuntas belajar sebanyak 4 dari 20 mahasiswa, sehingga 16 mahasiswa lainnya belum tuntas belajar atau $80 \%$, sedangkan pada siklus I sebanyak 10 dari 20 mahasiswa telah tuntas belajar atau 50\% dan mahasiswa yang belum tuntas belajar sebanyak 10 mahasiswa atau 50\%. Hasil belajar pada siklus I tersebut dirasakan oleh peneliti belum optimal, sehingga peneliti melanjutkan lagi pada pembelajaran siklus II.

Pengkajian data yang peneliti lakukan pada proses pembelajaran studi awal, siklus I, dan siklus II secara bertahap mengalami peningkatan yang lebih baik. Penguasaan terhadap materi pada proses pembelajaran tersebut dapat dilihat pada penilaian evaluasi mahasiswa. Jika pada siklus I ketuntasan belajar 
mahasiswa secara klasikal hanya 50\% atau mahasiswa yang tuntas belajar sebanyak 10 dari 20 mahasiswa, sehingga 10 mahasiswa lainnya belum tuntas belajar atau 50\%, sedangkan pada siklus II sebanyak 16 dari 20 mahasiswa telah tuntas belajar atau $85 \%$ dan mahasiswa yang belum tuntas belajar sebanyak 4 mahasiswa atau 15\%. Hasil belajar pada siklus II tersebut dirasakan oleh peneliti sudah ada peningkatan, sehingga peneliti tidak melanjutkan lagi pada pembelajaran siklus III.

\section{F. KESIMPULAN}

Perbandingan mahasiswa yang tuntas belajar dengan mahasiswa yang belum tuntas belajar berbanding terbalik antara studi awal, siklus I, dan siklus II. Data tersebut menunjukkan bahwa hasil belajar mahasiswa mengalami peningkatan. Ketuntasan belajar secara klasikal pada studi awal, siklus I, dan siklus II mengalami peningkatan yaitu dari 15\%, 50\% dan $85 \%$ dan ketidaktuntasan atau belum tuntas belajar mahasiswa secara klasikal menurun yaitu dari 85\%, 50\%, dan15\%. Jika dilihat dari data diatas maka dapat disimpulkan bahwa penggunaan metode sight reading dapat meningkatkan hasil belajar mata kuliah Piano 2 semeter genap tahun ajaran 2013/2014 jurusan pendidikan seni musik FBS UNY.

\section{DAFTAR PUSTAKA}

Aqib, Zainal. 2007. Penelitian Tindakan Kelas. Bandung: Yrama Widya.

Arikunto, Suharsimi (dkk). 2007. Penelitian Tindakan Kelas. Jakarta: Bumi Aksara.

Jamalus. 1988. Pengajaran Musik Melalui Pengalaman Musik. Jakarta: Depdikbud.

Kennedy, M., 2008. The Concise Oxford Dictionary of Music. London: Oxford University Press.

Kodiyat, Latifah., 2004. Istilah-Istilah Musik. Jakarta: Depdikbud. 
Last, Joan., 2005. Interpretation in Piano Study. New York: Oxford University Press.

Sukardi, 2008. Metodologi Penelitian Pendidikan: Kompetensidan Praktiknya. Jakarta: Bumi Aksara.

Wisbey, A.Stanley., 2006. Music as The Source of Learning. Baltimore: University Park Press. 